\title{
Temporal and spatial water use on irrigated and nonirrigated pasture-based dairy farms
}

\author{
C. D. Higham, ${ }^{*} \dagger^{1}$ D. Horne, $\dagger$ R. Singh, $\dagger$ B. Kuhn-Sherlock, ${ }^{*}$ and M. R. Scarsbrook ${ }^{*}$ \\ *DairyNZ-Policy and Advocacy, Private Bag 3221, Hamilton 3240, New Zealand \\ †Institute of Agriculture and Environment, Massey University, Private Bag 11222, Palmerston North 4474, New Zealand
}

\begin{abstract}
Robust information for water use on pasture-based dairy farms is critical to farmers' attempts to use water more efficiently and the improved allocation of freshwater resources to dairy farmers. To quantify the water requirements of dairy farms across regions in a practicable manner, it will be necessary to develop predictive models. The objectives of this study were to compare water use on a group of irrigated and nonirrigated farms, validate existing water use models using the data measured on the group of nonirrigated farms, and modify the model so that it can be used to predict water use on irrigated dairy farms. Water use data were collected on a group of irrigated dairy farms located in the Canterbury, New Zealand, region with the largest area under irrigation. The nonirrigated farms were located in the Manawatu region. The amount of water used for irrigation was almost 52-fold greater than the amount of all other forms of water use combined. There were large differences in measured milking parlor water use, stock drinking water, and leakage rates between the irrigated and nonirrigated farms. As expected, stock drinking water was lower on irrigated dairy farms. Irrigation lowers the dry matter percentage of pasture, ensuring that the amount of water ingested from pasture remains high throughout the year, thereby reducing the demand for drinking water. Leakage rates were different between the 2 groups of farms; $47 \%$ of stock drinking water was lost as leakage on nonirrigated farms, whereas leakage on the irrigated farms equated to only $13 \%$ of stock drinking water. These differences in leakage were thought to be related to regional differences rather than differences in irrigated versus nonirrigated farms. Existing models developed to predict milking
\end{abstract}

Received October 24, 2016.

Accepted April 22, 2017.

${ }^{1}$ Corresponding author: caleb.higham@dairynz.co.nz parlor, corrected stock drinking water, and total water use on nonirrigated pasture-based dairy farms in a previous related study were tested on the data measured in the present research. As expected, these models performed well for nonirrigated dairy farms but provided poor predictive power for irrigated farms. Partial least squares regression models were developed specifically to simulate corrected stock drinking water, milking parlor water, and total water use on irrigated dairy farms.

Key words: water use, water efficiency, irrigation, milking parlor, pasture system

\section{INTRODUCTION}

The area of land under irrigation doubled from 1950 to 2000 (Molle et al., 2010), and global water use for irrigated agriculture now accounts for approximately $70 \%$ of total freshwater withdrawals (United Nations Educational, Scientific and Cultural Organization, 2015). Water scarcity is an issue in many water basins (Smakhtin et al., 2004; Molle et al., 2010), and 20\% of the world's aquifers are being overused (Gleeson et al., 2012). Therefore, the focus on optimizing and managing agricultural water usage is increasing (Scarsbrook and Melland, 2015; Dillon et al., 2016). This focus is needed because the world population is estimated to reach 9.7 billion people by 2050. The amount of food produced will need to increase by $70 \%$ to feed this population (FAO, 2009; United Nations Department of Economic and Social Affairs, 2015); therefore, the pressure on water resources will increase further.

Dairy cow water intake studies have concentrated on confinement systems (Murphy et al., 1983; Meyer et al., 2004; Cardot et al., 2008), and only recent articles are available on pasture-based dairy farms (Higham et al., 2017; Murphy et al., 2017). Significant data are available on the amount of water used for irrigation (Armstrong et al., 2000; Doll and Siebert, 2002), and water use on nonirrigated pasture-based dairy farms in New Zealand has been quantified (Higham et al., 2017). However, data for other water uses on irrigated 
dairy farms, including stock drinking water (SDW), and milking parlor water use (MPW) remain limited.

The study of Higham et al. (2017) showed the seasonal nature of water use on pasture-based farms (milking from spring to autumn) and the importance of milk production and climatic variables as drivers of water use. However, further research is needed on the water requirements of dairy farms that use irrigation. As the models developed by Higham et al. (2017) do not include or account for DM percentage in the feed (and therefore ingested water), we do not expect them to reliably predict water use on irrigated farms.

As the allocation of water resources gets close to available limits in waterways in dairying regions, accurate water use figures for SDW and MPW are required. This information is needed to minimize the risks of underestimating water used (where not enough water is left to maintain environmental water flows) or overestimating water used (where the water resource is underused). Water use data are also required for water footprinting studies (Ridoutt and Pfister, 2010; Zonderland-Thomassen and Ledgard, 2012), which can be used to calculate abstractive and consumptive water use for analysis of the water "embedded" in milk products. This also allows the effect of current and future water extraction patterns to be assessed. The objectives of the current study were to evaluate the accuracy of previously described water requirement models and to develop new models for predicting water requirements on irrigated dairy farms.

\section{MATERIALS AND METHODS}

Water use was measured on 20 irrigated dairy farms in the Canterbury region $\left(-43^{\circ} \mathrm{S}, 172^{\circ} \mathrm{E}\right)$ and 22 nonirrigated dairy farms in the Manawatu region $\left(-40^{\circ} \mathrm{S}\right.$, $176^{\circ} \mathrm{E}$ ) of New Zealand. Dairy farms with water meters, telemetry, and data loggers already installed (as required by regional council rules) were selected, and, where appropriate, additional water meters and data loggers were installed as piping infrastructure allowed. In this manner, as many different water uses as possible were monitored. A complete set of total water $[\mathbf{T W}$, calculated as MPW + SDW; irrigation water (IW) is excluded from TW] use, MPW, and SDW data were recorded on 3 farms in the Canterbury region and 10 farms in the Manawatu region. In addition, individual MPW, SDW, and TW values were measured on 11, 1, and 7 farms in the Canterbury region and 5, 1, and 3 farms in the Manawatu region, respectively. The IW use data were available on 10 of the Canterbury farms as the rest were not telemetered. A total of 29 and 23 years of data (not including submetering) was collected from the irrigated and nonirrigated farms, respectively.

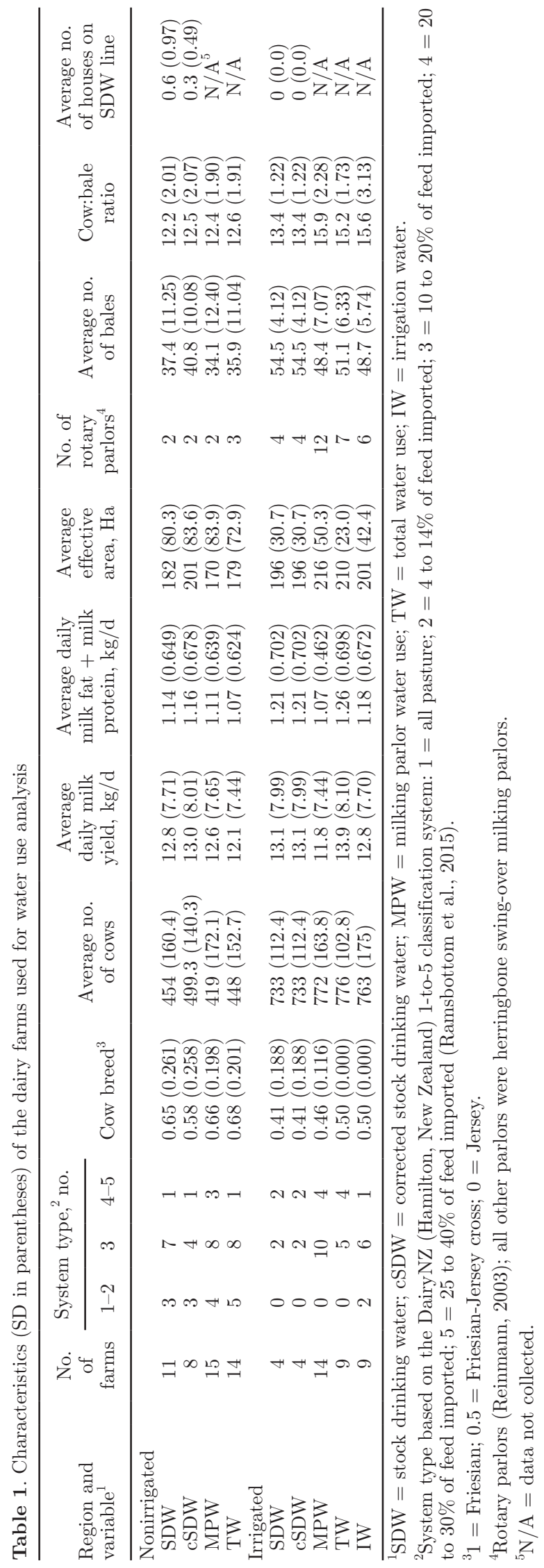

Journal of Dairy Science Vol. 100 No. 8, 2017 


\section{Data Collection}

Water use data were collected continuously at 15-min intervals using water meters with either telemetry or data loggers. Data loggers were manually downloaded every 4 to 6 mo. Relevant farm data, such as the milking platform area, herd size, parlor type (i.e., herringbone or rotary), and cow breed, were collected (Table 1). Farms were categorized according to the type of production system based on the amount of supplementary feed imported onto the farm (Ramsbottom et al., 2015). The number of houses taking water from the stock drinking water line was collected through a questionnaire.

\section{Farm Descriptions}

Descriptions of the study farms are presented in Table 1. Herd size (peak numbers milked) ranged from 480 to 1,420 cows on the irrigated farms and 200 to 1,050 cows on the nonirrigated farms. Daily (24-h) climate data, such as maximum and minimum temperature $\left({ }^{\circ} \mathrm{C}\right)$, rainfall $(\mathrm{mm})$, solar radiation $\left(\mathrm{MJ} / \mathrm{m}^{2}\right)$, wind run $(\mathrm{km})$, and Priestley-Taylor potential evapotranspiration $(\mathrm{mm})$, were obtained from the virtual climate station network (VCSN) site (Cichota et al., 2008) closest to each farm. The VCSN used data from weather stations and extrapolated it over a $5 \mathrm{~km} \times 5 \mathrm{~km}$ grid across New Zealand. From the VCSN, the average yearly rainfall, daily maximum temperature, minimum temperature, potential evapotranspiration, and solar radiation for the Canterbury farms were $637 \mathrm{~mm}, 16.8^{\circ} \mathrm{C}, 6.2^{\circ} \mathrm{C}, 2.1$ $\mathrm{mm}$, and $13.1 \mathrm{MJ} / \mathrm{m}^{2}$, respectively. For the Manawatu region, the corresponding values were $1,017 \mathrm{~mm}$, $17.8^{\circ} \mathrm{C}, 8.3^{\circ} \mathrm{C}, 2.3 \mathrm{~mm}$, and $13.8 \mathrm{MJ} / \mathrm{m}^{2}$, respectively. Average yearly milk volume and milk fat plus milk protein yield were $4,576 \mathrm{~L}$ and $416 \mathrm{~kg}$, respectively, on the irrigated farms and 4,501 L and $401 \mathrm{~kg}$, respectively, on the nonirrigated farms. Over the 2 yr of measurement, average milk fat and milk protein content was 4.92 and $3.90 \%$, respectively, across all of the irrigated farms and 4.88 and $3.78 \%$, respectively, on the nonirrigated farms (DairyNZ and Livestock Improvement Corporation, 2014, 2015). All monitored farms in Canterbury grazed cows off the farm during winter; in comparison, $79 \%$ of

Table 2. Farm variables used in the water use analysis

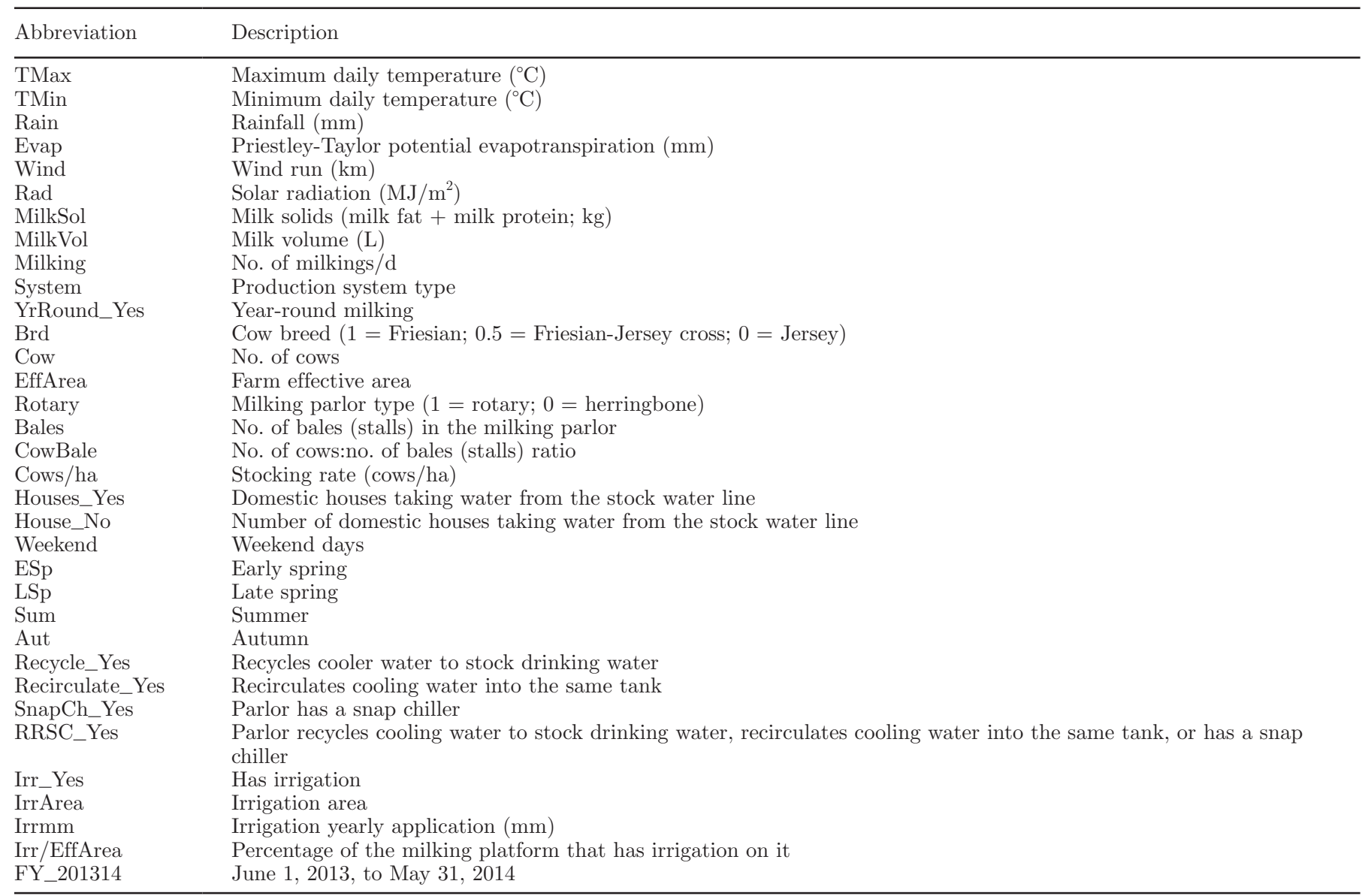


farms $(\mathrm{n}=15)$ in the Manawatu region winter grazed off farm for an average of $7.6 \mathrm{wk}$ (range $=6-9.5 \mathrm{wk}$ ).

\section{Data Management and Calculations}

Water use data were imported into Hilltop software (Kmoch et al., 2015). The water use data from data loggers were compared with the manual readings of the water meters. Where a difference existed between the data logger and the water meter $(>2 \%)$, the data logger water use data were adjusted to match the manual reading of the water meter; this occurred once on 5 farms. The data were checked for gaps and consistency. When gaps were found, the data were truncated, removing any partial days of data.

On 16 farms TW was measured along with either SDW or MPW. The SDW or MPW was subtracted from TW to calculate the unknown MPW (on 13 farms) or SDW (on 3 farms) via coding in Hilltop software in the same way as reported previously (Higham et al., 2017). The SDW data were exported from Hilltop software for formatting and analysis in Microsoft Excel (Microsoft Inc., Redmond, WA). Stock drinking water was exported in 15-min intervals, and MPW, TW, and IW were exported as daily volumes. The volume of water taken from the stock drinking water line by houses was corrected for as previously reported (Higham et al., 2017).

\section{Leakage Adjustment}

Individual farm SDW data were run through an $\mathrm{R}$ Software script (R Core Team, 2015) to adjust for wa- ter lost from the distribution system (i.e., water leakage). The script was based on a modification of the "night-time flow, leakage estimation" method (Tabesh et al., 2009; Cheung et al., 2010) as explained and developed by Higham et al. (2017). The output of the script included the SDW value and the corrected SDW (cSDW).

\section{Statistical Analyses}

The ability of the models developed by Higham et al. (2017) to predict SDW, MPW, and TW on nonirrigated farms was evaluated using the data collected from the current irrigated and nonirrigated farms. Evaluation methods included plots of the predicted versus measured data, the coefficient of determination of the line of best fit, Pearson correlation coefficients, root mean squared error (RMSE), Nash-Sutcliffe efficiency (NSE), percentage bias, and RMSE observations standard deviation ratio (Moriasi et al., 2007).

Because 2 full years of data were not available for some water use categories, a 365-d moving average was calculated when data from 5 or more farms were available. The average of the individual 365-d moving averages was calculated as the overall average of the water use. Standard deviations were calculated for the whole period of the 365 -d averages.

\section{Partial Least Squares Modeling}

Univariate polynomial partial least squares (PLS) regression modeling was used to evaluate the ability of a combination of different collinear variables to predict

Table 3. Average 365-d and peak water use measurements (L/cow per day) for stock drinking water (SDW), corrected SDW (cSDW), leakage, milking parlor water use (MPW), total water (TW), and irrigation water (IW)

\begin{tabular}{|c|c|c|c|c|c|c|}
\hline \multirow[b]{2}{*}{ Water use } & \multicolumn{3}{|c|}{ Nonirrigated } & \multicolumn{3}{|c|}{ Irrigated } \\
\hline & Farms (no.) & Average (SD) & Peak & Farms (no.) & Average (SD) & Peak \\
\hline SDW & 11 & $74(28.1)$ & 162 & 4 & $28(17.1)$ & 68 \\
\hline $\mathrm{cSDW}^{1}$ & 8 & $33(15.8)$ & 88 & 4 & $25(15.3)$ & 61 \\
\hline Leakage $^{2}$ & 8 & $38(17.8)$ & 106 & 4 & $4(5.5)$ & 41 \\
\hline Leakage $\%^{3}$ & 8 & 46.7 & & 4 & 13.0 & \\
\hline MPW & 15 & $50(20.4)$ & 85 & 14 & $64(33.8)$ & 118 \\
\hline $\mathrm{TW}^{4}$ & 14 & $120(38.0)$ & 197 & 9 & $94(29.4)$ & 220 \\
\hline IW & & & & 9 & 4,880 & \\
\hline $\mathrm{AMD}^{5} \mathrm{SDW}$ & 11 & $90(26.8)$ & & & $39(13.6)$ & \\
\hline AMD cSDW & 8 & $41(14.0)$ & & & $35(11.9)$ & \\
\hline AMD MPW & 15 & $66(7.5)$ & & & $90(9.3)$ & \\
\hline AMD TW & 12 & 149 (19.1) & & & $107(25.7)$ & \\
\hline
\end{tabular}

${ }^{1} \mathrm{cSDW}=\mathrm{SDW}-$ leakage.

${ }^{2}$ Leakage rate $(\mathrm{L} /$ cow per day) calculated where $\mathrm{n}>5$ except Canterbury farms $(\mathrm{n}=4)$.

${ }^{3}$ Leakage percentage rates were calculated on individual farms and then averaged across farms.

${ }^{4} \mathrm{TW}=\mathrm{SDW}+\mathrm{MPW}$.

${ }^{5} \mathrm{AMD}=$ average milking day; from September (spring) to February (summer). 
SDW, cSDW, MPW, and TW use (Wold et al., 2001; Sobek et al., 2005; Abudu et al., 2011) on irrigated farms. The starting PLS models included all relevant variables (Table 2). This was followed by an analysis in which factors of lowest influence (lowest standardized coefficient) were removed one at a time to give models with a range of predictive powers (i.e., predicted coefficient of determination compared with that of the starting model). To allow for greater flexibility of use depending on data availability, 3 or 4 models are reported here: the initial model with all variables and highest coefficient of determination (model 1), the "best" model that maintained a good coefficient of determination and had a lower number of variables (model 2), and 1 or 2 simple models with the minimum number of variables (models 3 and 4). Cross-validation was carried out using a "leave group out" approach with
50 randomly selected groups, each consisting of $2 \%$ of the data. Response variables were $\log _{10}$ transformed to achieve homogeneity of variance. All PLS analyses were carried out using Minitab 16.2 (Minitab Inc., State College, PA).

\section{RESULTS}

Average and peak water use values for the irrigated and nonirrigated farms are presented in Table 3 . The IW use was approximately 51-fold greater than all other forms of water use combined (TW). The average milking day demand for SDW (from September to February) was $90 \mathrm{~L} /$ cow per day for the nonirrigated farms and $39 \mathrm{~L} /$ cow per day for the irrigated farms. The average amount of leakage from SDW was $47 \%$ on the nonirrigated farms and $13 \%$ on the irrigated farms. a)

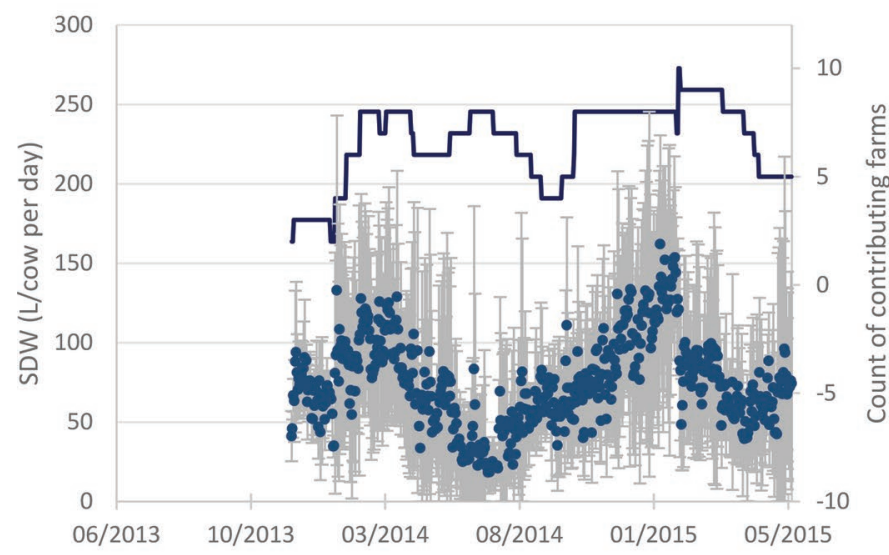

b)

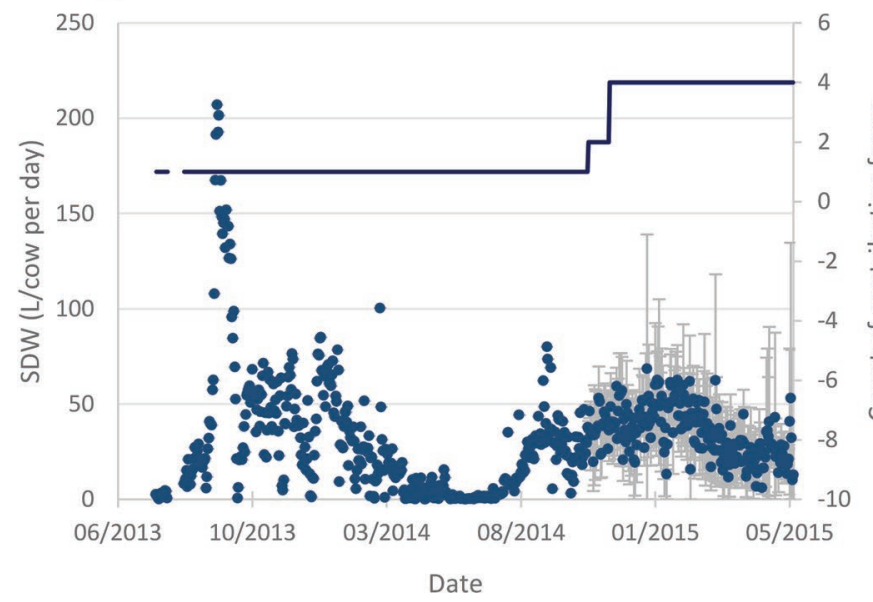

c)

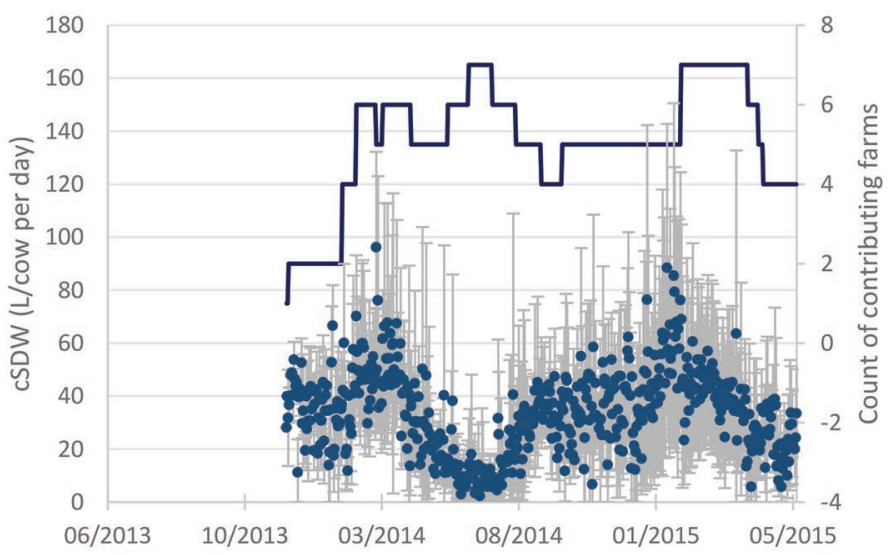

d)

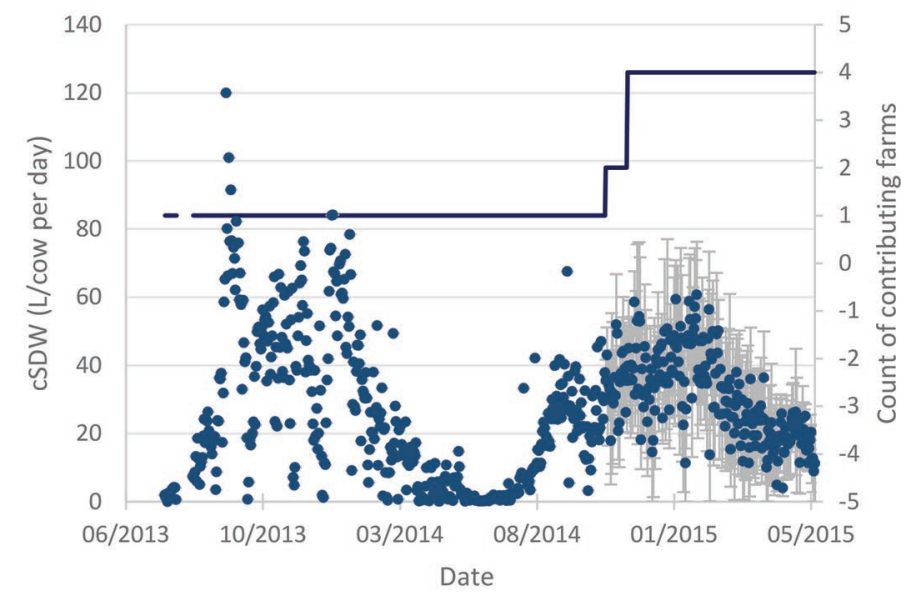

Figure 1. Average daily water use (L/cow per day; $\pm \mathrm{SD}$ ) and the count of farms contributing to the data (solid line) for (a) stock drinking water (SDW) on nonirrigated farms, (b) SDW on irrigated farms, (c) corrected SDW (cSDW) on nonirrigated farms, and (d) cSDW on irrigated farms. Color version available online. 
There was a seasonal pattern for SDW and cSDW for both irrigated and nonirrigated farms (Figure 1). The average milking day demand for MPW was $66 \mathrm{~L} / \mathrm{cow}$ per day for the nonirrigated farms and $90 \mathrm{~L} / \mathrm{cow}$ per day for the irrigated farms. The pattern of MPW and TW on irrigated and nonirrigated farms is presented in Figure 2.

\section{Evaluation of Water Use Model Predictions}

Table 4 shows the ability of the cSDW model 3, MPW model 3, and TW model 3 produced by Higham et al. (2017) for a different region (Waikato, New Zealand) to predict cSDW, MPW, and TW for the nonirrigated and irrigated farms in the Manawatu and Canterbury regions. As expected, the existing models predicted all water uses much better for nonirrigated farms than for irrigated farms; all irrigated models had worse lines of best-fit slopes as indicated by the greater percentage bias (i.e., the models both under- and overestimated water use on irrigated farms to a greater extent than on nonirrigated farms; Table 4). For irrigated farms the NSE values were low $(<0.5)$ and for cSDW the NSE value was below 0 , indicating that the mean is a better predictor than the model. This showed that the model is poor at predicting cSDW on irrigated dairy farms. Evaluation measures (i.e., NSE, percentage bias, RMSE observations standard deviation ratio) for the nonirrigated farms in the Manawatu region were consistent with evaluation measures of nonirrigated Waikato farms on which the model was based (Higham et al., 2017). a)

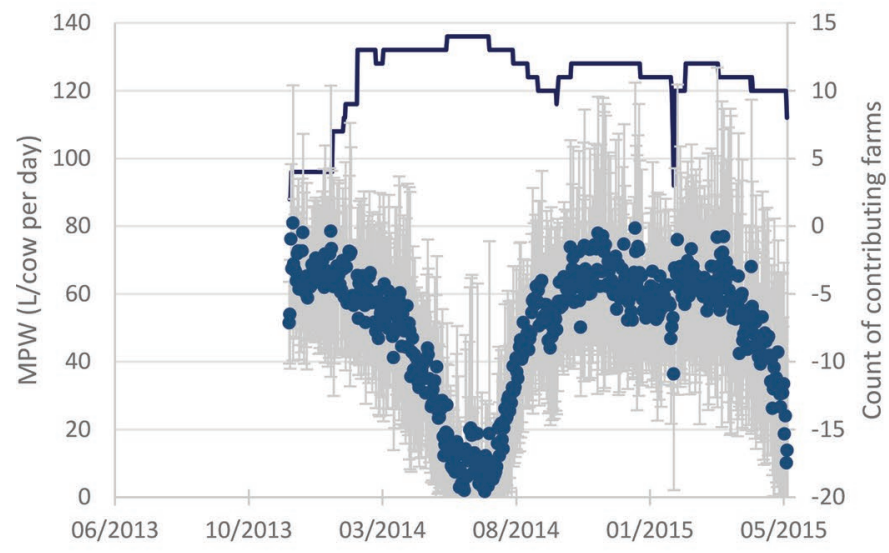

b)

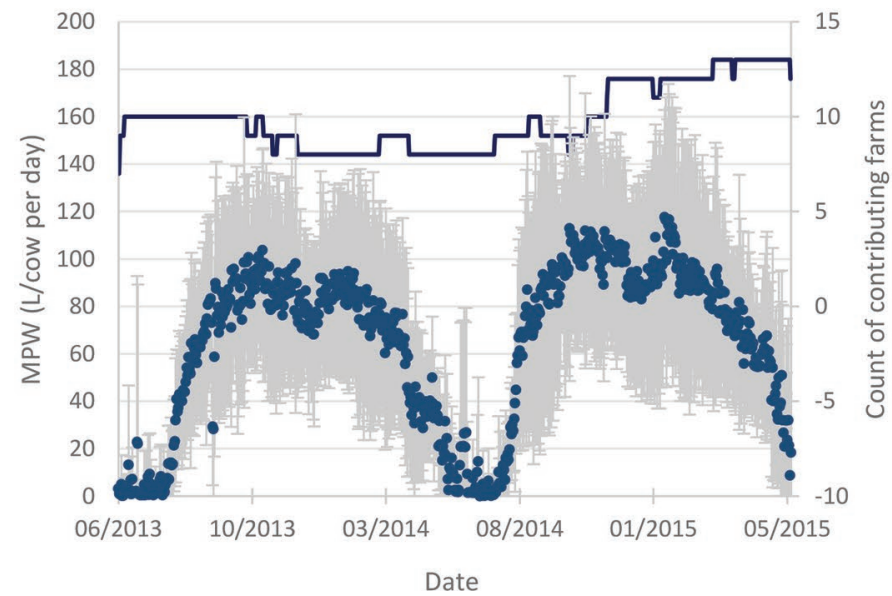

c)

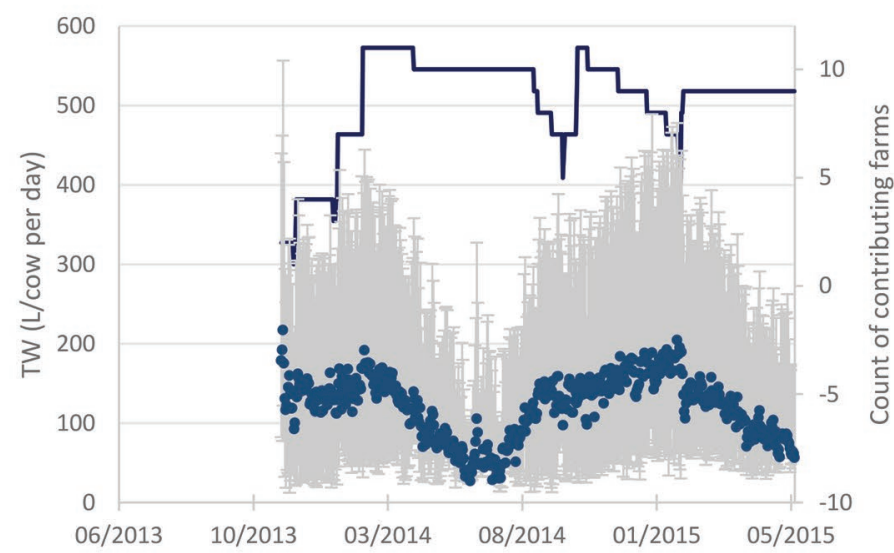

d)

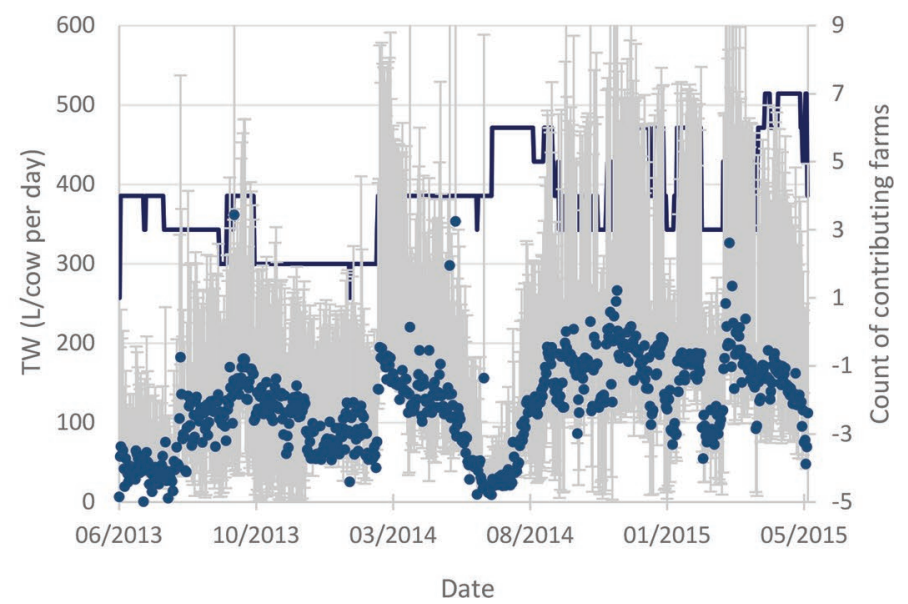

Figure 2. Average daily water use (L/cow per day; $\pm \mathrm{SD}$ ) and the count of farms contributing to the data (solid line) for (a) milking parlor water (MPW) use on nonirrigated farms, (b) MPW use on irrigated farms, (c) total water (TW) use on nonirrigated farms, and (d) TW use on irrigated farms (error bars up to 1,285 L/cow per day due to leaks truncated at $600 \mathrm{~L} /$ cow per day). Color version available online. 
Table 4. Corrected stock drinking water ${ }^{1}$ (cSDW), milking parlor water use (MPW), and total water ${ }^{2}$ (TW) model predictions compared with the measured or derived water use volumes on irrigated and nonirrigated pasture-based dairy farms

\begin{tabular}{|c|c|c|c|c|c|c|c|c|c|c|}
\hline Model prediction & $\begin{array}{l}\text { Prediction model } \\
\text { comparison with } \\
\text { measured data }\end{array}$ & $\mathrm{n}$ & $\begin{array}{l}\text { Line of } \\
\text { best fit } \\
\text { slope }^{3}\end{array}$ & $\begin{array}{l}\text { Line of } \\
\text { best fit Y } \\
\text { intercept }\end{array}$ & $\begin{array}{c}\text { Line of } \\
\text { best fit } \\
\text { R-squared }\end{array}$ & $\begin{array}{l}\text { Pearson } \\
\text { correlation } \\
\text { coefficient }^{6}\end{array}$ & $\mathrm{RMSE}^{7}$ & $\mathrm{NSE}^{8}$ & $\begin{array}{c}\text { Percentage } \\
\text { bias }^{9}\end{array}$ & $\mathrm{RSR}^{10}$ \\
\hline \multirow[t]{2}{*}{ MPW model 3} & Nonirrigated & 15 & 0.82 & 8.31 & 0.85 & 0.92 & 6.62 & 0.81 & -0.79 & 0.44 \\
\hline & Irrigated & 14 & 1.69 & -18.66 & 0.93 & 0.96 & 20.83 & 0.46 & 26.27 & 0.72 \\
\hline TW model 3 & Nonirrigated & 14 & 0.84 & 17.91 & 0.75 & 0.90 & 14.85 & 0.79 & 0.62 & 0.45 \\
\hline
\end{tabular}

${ }^{1} \mathrm{cSDW}=$ stock drinking water $(\mathrm{SDW})-$ leakage.

${ }^{2} \mathrm{TW}=\mathrm{SDW}+\mathrm{MPW}$.

${ }^{3} \mathrm{~L} /$ cow per day; optimum $=1$.

${ }^{4} \mathrm{~L} /$ cow per day; optimum $=0$.

${ }^{5}$ Optimum $=1$.

${ }^{6}$ Optimum $=1$ or -1 .

${ }^{7}$ Root mean squared error (L/cow per day); optimum $=1$.

${ }^{8}$ Nash-Sutcliffe efficiency; optimum $=1,>0$ is acceptable. If $<0$, then the mean is a better predictor than the model.

${ }^{9}$ Optimum $=0$; positive values mean underestimation and negative values mean overestimation.

${ }^{10} \mathrm{RSME}$ observations SD ratio; optimum $=0$.

Table 5. Partial least squares regression model equations (raw coefficients) for predicting corrected stock drinking water use $\left(\log _{10}\right.$ $\mathrm{cSDW})$ on irrigated pasture-based dairy farms $(\mathrm{n}=4)^{1}$

\begin{tabular}{|c|c|c|c|}
\hline Variable & Model 1 & Model 2 & Model 3 \\
\hline$\overline{\mathrm{R}^{2}}$ & 0.74 & 0.69 & 0.62 \\
\hline$P$ & $<0.001$ & $<0.001$ & $<0.001$ \\
\hline Constant & -0.9847 & 0.0324 & 0.0929 \\
\hline TMax & 0.0103 & & \\
\hline TMaxSq & 0.0001 & & \\
\hline TMin & -0.0086 & & \\
\hline TMinSq & 0.0005 & & \\
\hline Rain & -0.0312 & -0.0211 & \\
\hline RainSq & 0.0004 & & \\
\hline Evap & 0.0324 & 0.0768 & \\
\hline EvapSq & -0.0017 & & 0.0849 \\
\hline Wind & 0.0103 & & \\
\hline WindSq & -0.0018 & & \\
\hline Rad & 0.0077 & & \\
\hline RadSq & 0.0000 & & \\
\hline MilkSol & 0.0860 & 0.2008 & 0.3206 \\
\hline MilkSolSq & 0.0048 & & \\
\hline MilkVol & 0.0057 & & \\
\hline MilkVolSq & 0.0000 & & \\
\hline Milking & 0.1740 & 0.1913 & \\
\hline System & 0.1505 & & \\
\hline Brd & -0.0970 & & \\
\hline Cow & 0.0000 & & \\
\hline EffArea & 0.0001 & & \\
\hline Bales & -0.0004 & & \\
\hline CowBale & 0.0115 & & \\
\hline Cows/ha & 0.0582 & & \\
\hline FY_201314 & -0.0138 & & \\
\hline Weekend & -0.0020 & & \\
\hline $\mathrm{ESp}$ & 0.3045 & & \\
\hline LSp & 0.0575 & & \\
\hline Sum & 0.0507 & & \\
\hline Aut & -0.0109 & & \\
\hline IrrArea & 0.0005 & & \\
\hline Irrmm & 0.0005 & 0.0011 & 0.0012 \\
\hline Irr/EffArea & 0.0015 & & \\
\hline
\end{tabular}

${ }^{1} \mathrm{~A}$ list of variables is presented in Table 2 .

\section{PLS Regression Models}

The PLS regression models were developed for cSDW, MPW, and TW on irrigated farms, and the results are presented in Tables 5, 6, and 7, respectively. A total of 3, 4, and 4 models were produced for cSDW, MPW, and TW, respectively, with coefficient of determination values ranging between 0.62 and 0.74 . The cSDW model 2 (best model) had a coefficient of determination of 0.69 , and the predictive equation (equation 1 ) is presented later. The PLS loading plot of cSDW model 2 is presented in Figure 3a, where the first component is dominated by milk production variables and potential evapotranspiration. Increases in this component increase cSDW the most. The second component is dominated by irrigation and rainfall; increases in this component increase cSDW, but to a lesser extent than component 1. The MPW model 3 (best model) had a coefficient of determination of 0.65 . The PLS loading plot of MPW model 3 is presented in Figure 3b, where milk production variables and the number of milkings in a day drive MPW. The TW model 2 had a coefficient of determination of 0.66. The PLS loading plot for TW model 2 is presented in Figure 3c, where the main drivers of component 1 are milk production variables and potential evapotranspiration. The equations for the best models - cSDW model 2 (equation 1), MPW model 3 (equation 2), and TW model 2 (equation 3) - are as follows. The model prediction results were corrected for a constant bias by the addition of $1.25,15$, and -6 to the transformed water uses, respectively. The results of the bias correction are evident in the results of the model evaluation in Table 8 . The high values (all $>0.96$, with a maximum value of 1 ) for the NSE indicates that the 
plot of observed versus simulated data fits the 1:1 line (NSE $<0$ indicates that the mean is a better predictor than the model).

$\log \mathrm{CDW}($ model $2+1.25)=0.0324+0.2008 \times$ MilkSol

$-0.0211 \times$ Rain $+0.0768 \times$ Evap $+0.1913 \times$ Milking

$+0.0011 \times$ Irrmm

LogMPW $($ model $3+15)=0.2538+0.4266 \times$ MilkSol

$-0.0325 \times \mathrm{MilkSol}^{2}+0.0230 \times \operatorname{Rad}-0.0008 \times \operatorname{Rad}^{2}-$

$0.0419 \times$ Evap $+0.0115 \times$ Evap $^{2}+1.4137 \times$ Milking -

$0.4786 \times$ Milking $^{2}$ $\log \mathrm{TW}($ model $2-6)=5.0573-0.1531 \times$ CowBale +0.0487

$\times \mathrm{MilkVol}+0.0881 \times \mathrm{MilkSol}-0.2149 \times \mathrm{MilkSol}^{2}+0.0878$

$\times$ Evap $-0.0110 \times$ Evap $^{2}+0.3372 \times$ Milking -0.0400

$\times$ Milking $^{2}+0.7393 \times$ Rotary $-0.0276 \times \operatorname{Irr} /$ EffArea

$+0.6851 \times$ Houses_Yes $-0.0674 \times$ Recycle_Yes

Abbreviations used in the models are presented in Table 2. The results of the model evaluation for irrigated farms for cSDW model 2, MPW model 3, and TW model 2 are presented in Table 8 . The predicted versus measured or derived plots for cSDW, MPW, and

[2] TW are presented in Figures 4a, b, and c, respectively.

Table 6. Partial least squares regression model equations (raw coefficients) for predicting milking parlor water use $\left(\log _{10} \mathrm{MPW}\right)$ on irrigated pasture-based dairy farms $(\mathrm{n}=12)^{1}$

\begin{tabular}{|c|c|c|c|c|}
\hline Variable & Model 1 & Model 2 & Model 3 & Model 4 \\
\hline$\overline{\mathrm{R}^{2}}$ & 0.71 & 0.70 & 0.65 & 0.65 \\
\hline$P$ & $<0.001$ & $<0.001$ & $<0.001$ & $<0.001$ \\
\hline Constant & -4.4764 & -2.2834 & 0.3040 & 0.3389 \\
\hline TMax & 0.0139 & & & \\
\hline TMaxSq & -0.0002 & & & \\
\hline TMin & 0.0258 & & & \\
\hline TminSq & -0.0016 & & & \\
\hline Rain & 0.0025 & & & \\
\hline RainSq & -0.0001 & & & \\
\hline Evap & 0.0135 & & 0.0424 & \\
\hline EvapSq & -0.0087 & & -0.0002 & \\
\hline Wind & -0.0172 & & & \\
\hline WindSq & 0.0005 & & & \\
\hline $\operatorname{Rad}$ & 0.0084 & & 0.0040 & \\
\hline RadSq & 0.0000 & & -0.0003 & \\
\hline MilkSol & 0.4398 & 0.6033 & 0.4452 & 0.4981 \\
\hline MilkSolSq & -0.1462 & -0.1344 & -0.0492 & -0.0635 \\
\hline MilkVol & 0.0306 & & & \\
\hline MilkVolsq & -0.0011 & & & \\
\hline Milking & 0.3759 & 1.3298 & 1.4020 & 1.3925 \\
\hline Milking_Sq & -0.0979 & -0.4401 & -0.4711 & -0.4679 \\
\hline System & -0.4015 & & & \\
\hline Brd & 1.9438 & 0.6197 & & \\
\hline Cow & 0.0001 & & & \\
\hline EffArea & -0.0007 & & & \\
\hline Rotary & -0.1794 & & & \\
\hline Bales & -0.0102 & -0.0413 & & \\
\hline CowBale & 0.0461 & & & \\
\hline Cow/ha & 0.5388 & 0.8966 & & \\
\hline Houses_Yes & -0.4452 & -0.3110 & & \\
\hline Irr/EffArea & 0.0250 & & & \\
\hline IrrArea & 0.0021 & 0.0062 & & \\
\hline Irrmm & 0.0006 & & & \\
\hline FY_201314 & -0.0966 & & & \\
\hline $\mathrm{ESp}$ & 0.5712 & & & \\
\hline LSp & 0.6351 & & & \\
\hline Sum & 0.5206 & & & \\
\hline Aut & 0.4263 & & & \\
\hline Weekend & -0.0238 & & & \\
\hline recyORrecircORsnap & 0.0770 & & & \\
\hline
\end{tabular}

${ }^{1} \mathrm{~A}$ list of variables is presented in Table 2 . 


\section{DISCUSSION}

A seasonal pattern was clear for SDW, cSDW, MPW, and TW in both the irrigated and nonirrigated farms. Although differences are evident, it should be noted that the data are confounded by differing region, farm and herd size, type of milking parlor, and age of infrastructure. The data should be interpreted as a range of values for different water uses across divergent regions and production systems. The data presented here for nonirrigated dairy farms in the Manawatu region are consistent with previous data published on nonirrigated dairy farms (Higham et al., 2017).

There were differences in water use on irrigated and nonirrigated pasture-based dairy farms, including the magnitude of the seasonal patterns between the 2 groups. This is reflective of the seasonal calving operation of
New Zealand dairy systems and changing climatic conditions between regions. Average SDW was $23 \%$ higher on nonirrigated farms than on irrigated farms despite the irrigated farms being in the Canterbury region and having some of New Zealand's warmest summer temperatures. Lower SDW on the irrigated farms was likely due to a combination of factors but largely attributable to irrigation and leakage rates. Leakage rates (47\%) on the nonirrigated farms $(\mathrm{n}=8)$ were much higher than on the irrigated farms $(\mathrm{n}=4 ; 13 \%)$. Possible explanations for this include soil type, geological activity, and age of infrastructure. The Manawatu (nonirrigated) region also has frequent earthquakes- 7,179 earthquakes in a $9,300-\mathrm{km}^{2}$ area over the trial period compared with 1,790 earthquakes in a $66,500-\mathrm{km}^{3}$ area in the Canterbury (irrigated) region (Earthquake Commission and GNS Science, 2016). Many dairy farms in

Table 7. Partial least squares regression model equations (raw coefficients) for predicting total water use $\left(\log _{10}\right.$ $\mathrm{TW})$ on irrigated pasture-based dairy farms $(\mathrm{n}=6)^{1}$

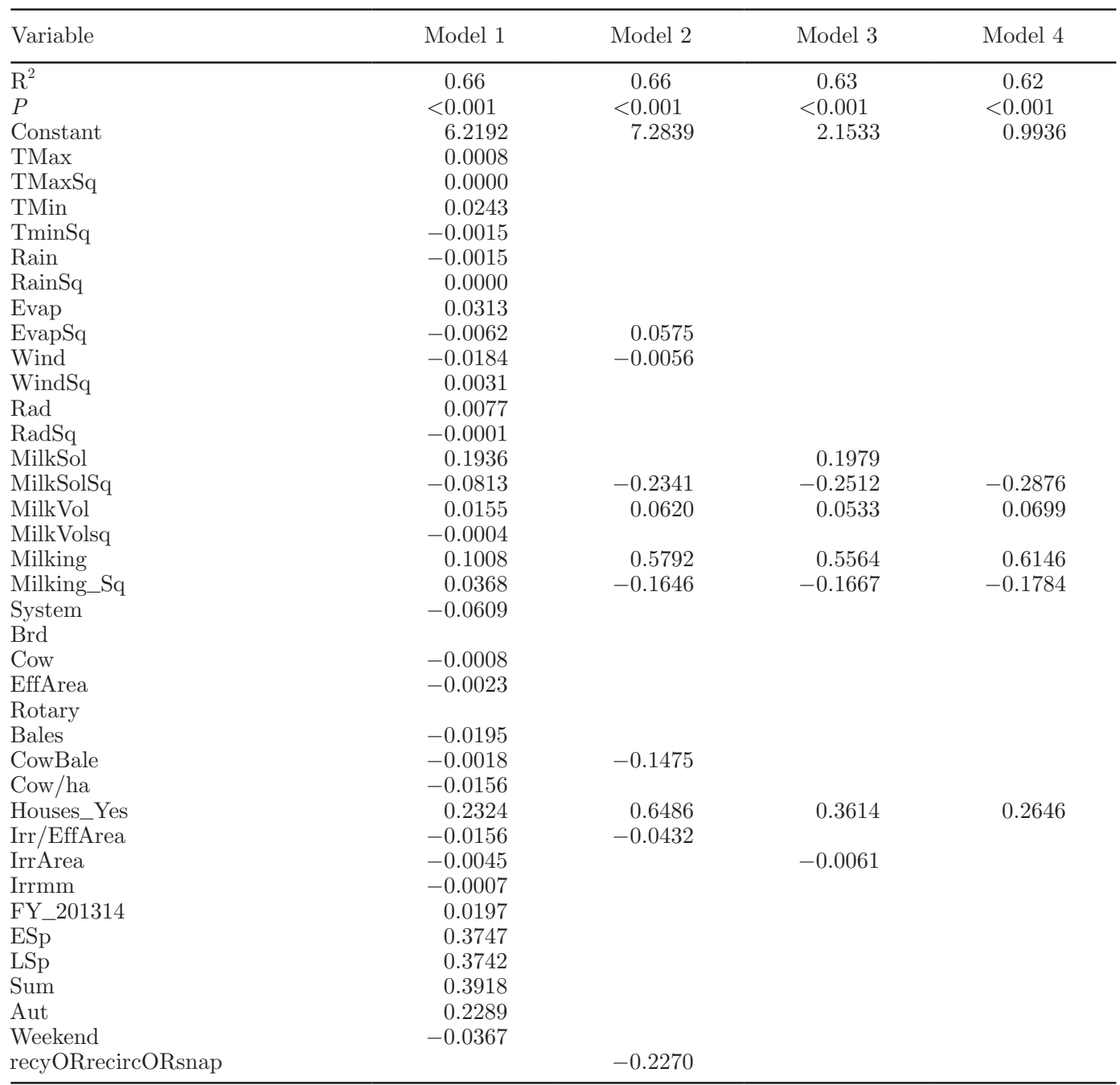

${ }^{1} \mathrm{~A}$ list of variables is presented in Table 2 . 
the Canterbury region were established in recent times, whereas dairying is a much older use of land in the Manawatu region, leading to differences in the age of infrastructure. We do not have information on the age of the infrastructure on farms to analyze the effect it had on leakage rates. Further work is needed to confirm the cause of the higher leakage rates and to understand whether water leakage can be reduced on all farms or whether farms with certain characteristics can be targeted. Although the leakage component explained the majority of the difference in SDW between the 2 regions, irrigated pasture also influenced SDW. This influence was evident in the cSDW values being $8 \mathrm{~L} /$ cow per day (24\%) higher on average and $27 \mathrm{~L} /$ cow per day $(31 \%)$ higher at peak on the nonirrigated farms compared with the irrigated farms. The main reason for this is the moisture status of the irrigated pasture; the DM content of pasture on an irrigated research farm in Canterbury is typically between 15 and $25 \%$ for the whole season (A. Clement, DairyNZ, Lincoln, New Zealand; personal communication, 2016). In contrast, the DM content of nonirrigated pasture on a research farm in the Waikato region, which can experience dry summers similar to the Manawatu region, can average $40 \%$ in dry summers (C. Roach, DairyNZ, Hamilton, New Zealand; personal communication, 2016). The reduced DM content of pasture on irrigated farms results in more water being ingested via grass than on nonirrigated farms (e.g., 120 vs. $30 \mathrm{~L} /$ cow per day), which reduces cow requirements for cSDW.

Average MPW over the milking period was $24 \mathrm{~L} /$ cow per day higher on irrigated farms than on nonirrigated farms. Possible explanations for the higher MPW on irrigated farms include the higher proportion of rotary milking parlors (86\%) in the irrigated region than rotary milking parlors $(26 \%)$ in the nonirrigated region (Higham et al., 2017). Higher numbers of staff employed may be another influence on MPW. Further consideration should be given to evaluating why MPW is higher on the irrigated farms, as this may allow water reductions to be made in the future.

On the irrigated farms, IW use was much greater than either SDW or MPW. Therefore, when all forms of water use are combined (i.e., TW + IW), water use on the irrigated dairy farms was approximately 39-fold greater than it was on nonirrigated farms. To put this in context, forgoing $1 \mathrm{~d}$ of irrigation would save as much water on some farms as that used in MPW over approximately $78 \mathrm{~d}$. Therefore, to reduce overall water use on irrigated dairy farms, focusing on increasing irrigation efficiency rather than reducing MPW may be more productive.

The cSDW model 3, MPW model 3, and TW model 3 developed by Higham et al. (2017) predicted water use on the nonirrigated dairy farms in this study with good accuracy and precision. Given the similarity in observed water use between both sets of nonirrigated

a)

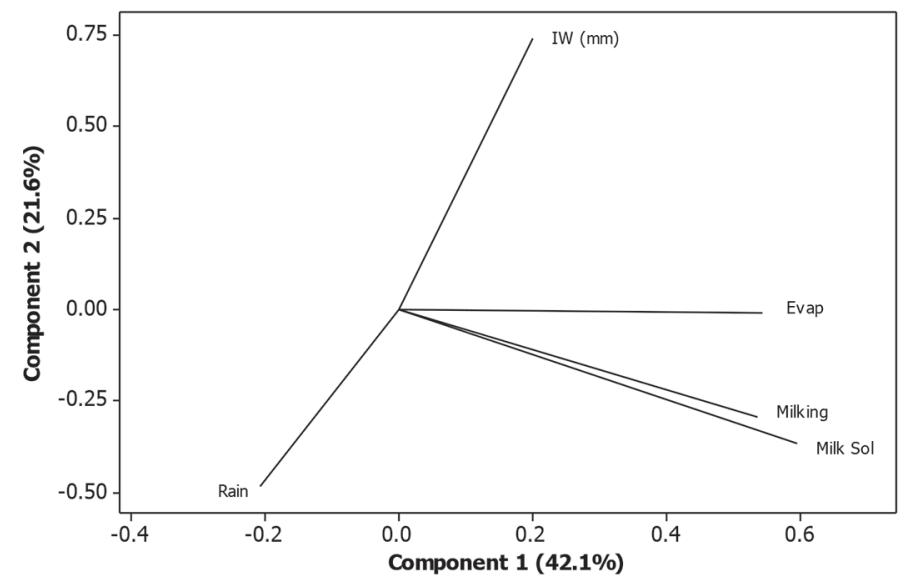

b)

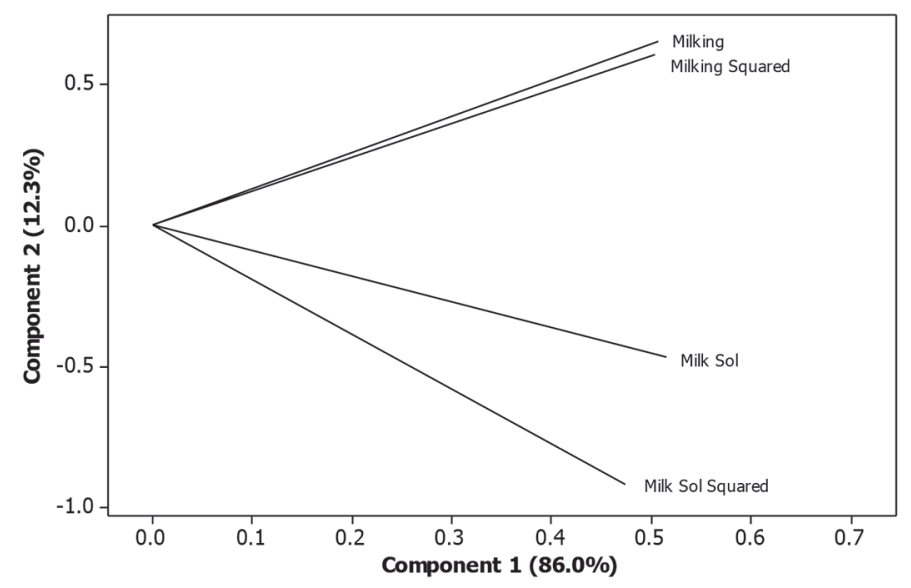

c)

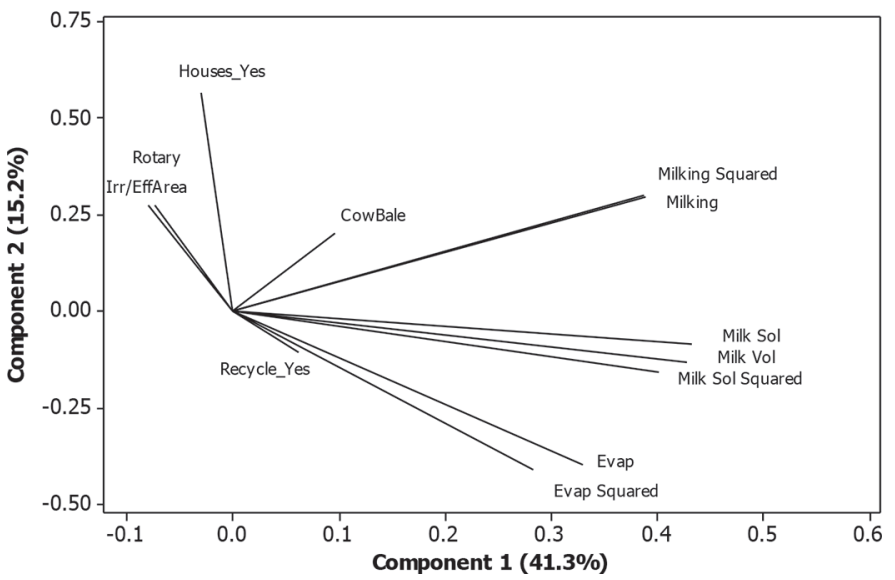

Figure 3. Partial least squares regression loading plots (variables defined in Table 4) for (a) corrected stock drinking water model 2, (b) milking parlor water use model 3 , and (c) total water use model 3 . 
farms, the success of the Higham et al. (2017) models is not surprising. It would suggest that we now have a good understanding of water use data on nonirrigated farms and have the ability to predict this water use. As expected, the models of Higham et al. (2017) were not able to predict cSDW, MPW, and TW, respectively, on irrigated pasture-based dairy farms. All models had poor line of best fit slopes, percentage bias, and NSE, and the cSDW model 3 predictions were less accurate than the mean water use on irrigated farms (NSE $<0)$. As the models described by Higham et al. (2017) were not able to predict water use on irrigated dairy farms, new PLS regression models were developed to predict cSDW, MPW, and TW on irrigated dairy farms. These new models performed well for the irrigated farms studied here. The models were very close to the observed water use and overestimated water use only from 0.1 to $2.8 \%$.

The water use figures and predictive models produced in this study will have implications for the management of water use on dairy farms. Farms in geologically active areas or on coarse-textured soils, older farms, or farms in areas with certain topography may require more leakage management than other farms, but further research is needed to investigate this. Water use prediction models will allow more realistic estimation of water use and water use patterns in both nonirrigated and irrigated regions to aid in the allocation of water and the management of water resources. The models will also allow water footprints to be calculated and regional footprints to be compared.

In this study, water meters already available on farms were used for monitoring to keep the cost down, and both telemetry and data loggers were used to collect data. Water meters were also installed on farms in the
Manawatu region where it was feasible in the water system. It was very difficult to ensure metering of all water sources on many farms because of complex water reticulation systems. Many older farms in the Manawatu region had been merged to form one larger farm, a consequence having fragmented water systems. This reduced the feasibility of collecting data because the cost of multiple water meters, data loggers, and installation was prohibitive. Data loggers were used as a less expensive data collection option than telemetry. However, this came with a greater workload in data collection and issues with battery life and suitable weatherproof housing to prevent moisture from damaging the data loggers. In future research, we recommend that thorough scoping of data collection options should be evaluated to ensure the data collection method chosen meets requirements and that telemetry be used where budget allows. The remote data access of telemetry systems allows for easy data monitoring, thus reducing workload significantly and increasing reliability.

\section{CONCLUSIONS}

On irrigated dairy farms, the water used for irrigation far exceeded all other forms of water use combined. Corrected SDW on the irrigated dairy farms was lower than that on nonirrigated dairy farms. This can be explained by the larger quantities of water ingested by the cows as they graze the irrigated pasture, which has lower DM. The models developed by Higham et al. (2017) were able to predict water use on the nonirrigated dairy farms of a different region. However, these models were not able to predict water use on irrigated farms. New PLS regression models were developed to predict cSDW, MPW, and TW on irrigated farms.

Table 8. Partial least squares regression model evaluation for irrigated farms

\begin{tabular}{|c|c|c|c|c|c|c|c|c|c|}
\hline $\begin{array}{l}\text { Prediction model comparison } \\
\text { with measured data }{ }^{1}\end{array}$ & $\mathrm{n}$ & $\begin{array}{l}\text { Line of } \\
\text { best fit } \\
\text { slope }^{2}\end{array}$ & $\begin{array}{c}\text { Line of } \\
\text { best fit } \\
\mathrm{Y} \text { intercept }{ }^{3}\end{array}$ & $\begin{array}{c}\text { Line of } \\
\text { best fit } \\
\text { R-squared }\end{array}$ & $\begin{array}{l}\text { Pearson } \\
\text { correlation } \\
\text { coefficient }^{5}\end{array}$ & $\mathrm{RMSE}^{6}$ & $\mathrm{NSE}^{7}$ & $\begin{array}{l}\text { Percentage } \\
\text { bias }^{8}\end{array}$ & $\mathrm{RSR}^{9}$ \\
\hline Irrigated cSDW model $2+1.25$ & 4 & 0.80 & 5.89 & 0.77 & 0.88 & 5.26 & 0.96 & -0.38 & 0.20 \\
\hline Irrigated total water model $2-6$ & 5 & 0.80 & 15.21 & 0.66 & 0.81 & 15.51 & 0.96 & -2.05 & 0.19 \\
\hline
\end{tabular}

${ }^{1}$ Corrected stock drinking water $(\mathrm{cSDW})=$ stock drinking water - leakage.

${ }^{2} \mathrm{~L} /$ cow per day; optimum $=1$.

${ }^{3} \mathrm{~L} /$ cow per day; optimum $=0$.

${ }^{4}$ Optimum $=1$.

${ }^{5}$ Optimum $=1$ or -1 .

${ }^{6}$ Root mean squared error (L/cow per day); optimum $=1$.

${ }^{7} \mathrm{Nash}-$ Sutcliffe efficiency; optimum $=1,>0$ is acceptable. If $<0$, then the mean is a better predictor than the model.

${ }^{8}$ Optimum $=0$; positive values mean underestimation and negative values mean overestimation.

${ }^{9} \mathrm{RSME}$ observations $\mathrm{SD}$ ratio; optimum $=0$. 
a)

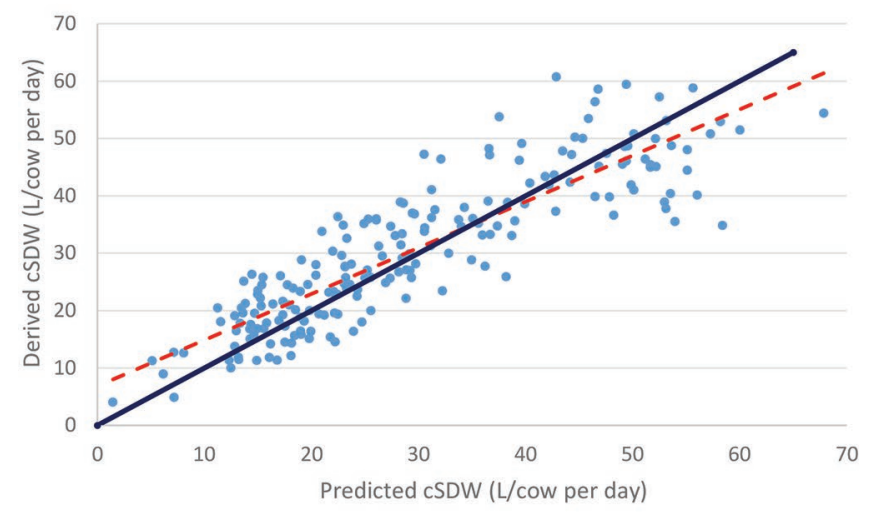

b)
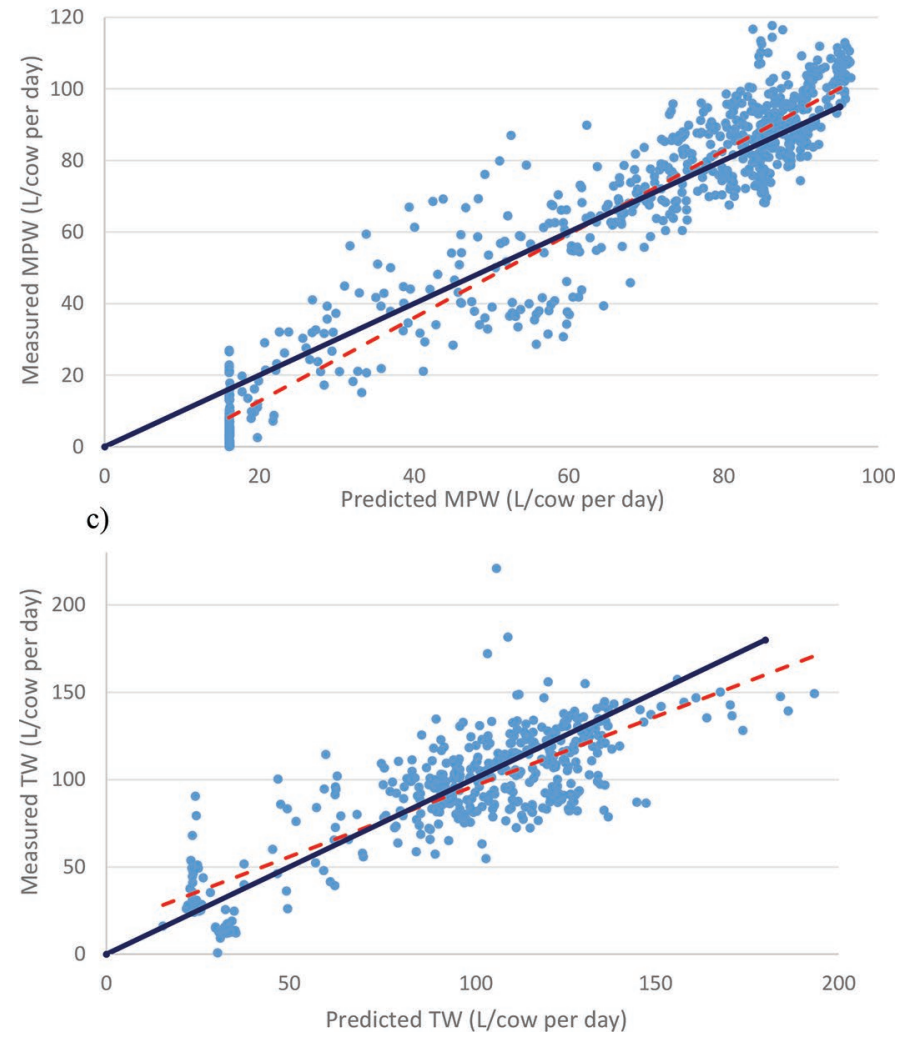

Figure 4. Measured or derived water use (number of farms $\geq 5$ ) versus predicted water use (dashed line of best fit) and solid 1:1 line for (a) corrected stock drinking water (cSDW) model $3\left(\mathrm{R}^{2}=0.77\right)$, (b) milking parlor water (MPW) use model $3\left(\mathrm{R}^{2}=0.90\right)$, and $(\mathrm{c})$ total water $(\mathrm{TW})$ use model $3\left(\mathrm{R}^{2}=0.72\right)$. Color version available online.

Further research is needed to evaluate the applicability of these models to other irrigated regions. The current study along with the preceding work described by Higham et al. (2017) suggest that we now have a reasonably comprehensive understanding of water use on New Zealand dairy farms and the ability to model this water use.

\section{ACKNOWLEDGMENTS}

The authors acknowledge the farmers involved and the effort they put into supplying data for this study. This work was supported by funding from New Zealand dairy farmers through DairyNZ Inc. and the Sustainable Dairying Water Accord (DairyNZ Inc.).

\section{REFERENCES}

Abudu, S., C. Cui, J. P. King, J. Moreno, and A. S. Bawazir. 2011. Modeling of daily pan evaporation using partial least squares regression. Sci. China Technol. Sci. 54:163-174.

Armstrong, D. P., J. E. Knee, P. T. Doyle, K. E. Pritchard, and O. A. Gyles. 2000. Water-use efficiency on irrigated dairy farms in northern Victoria and southern New South Wales. Aust. J. Exp. Agric. 40:643-653.

Cardot, V., Y. Le Roux, and S. Jurjanz. 2008. Drinking behavior of lactating dairy cows and prediction of their water intake. J. Dairy Sci. 91:2257-2264.

Cheung, P. B., G. V. Girol, N. Abe, and M. Propato. 2010. Night flow analysis and modeling for leakage estimation in a water distribution system. Pages 509-513 in Proc. The Tenth International Conference on Computing and Control for the Water Industry, Sheffield, UK. CRC Press, Boca Raton, FL.

Cichota, R., V. O. Snow, and A. B. Tait. 2008. A functional evaluation of virtual climate station rainfall data. N. Z. J. Agric. Res. $51: 317-329$.

DairyNZ and Livestock Improvement Corporation. 2014. New Zealand dairy statistics 2013-14. Accessed September 2016. http://www. dairynz.co.nz/publications/dairy-industry/new-zealand-dairystatistics-2013-14/.

DairyNZ and Livestock Improvement Corporation. 2015. New Zealand dairy statistics 2014-15. Accessed September 2016. http://www. dairynz.co.nz/publications/dairy-industry/new-zealand-dairystatistics-2014-15/.

Dillon, E. J., T. Hennessy, C. Buckley, T. Donnellan, K. Hanrahan, B. Moran, and M. Ryan. 2016. Measuring progress in agricultural sustainability to support policy-making. Int. J. Agric. Sustain. 14:31-44.

Doll, P., and S. Siebert. 2002. Global modeling of irrigation water requirements. Water Resour. Res. 38:8-1-8-10.

Earthquake Commission and GNS Science. 2016. Quake Search. Vol. 2016. GeoNet. Accessed September 2016. http://quakesearch. geonet.org.nz/.

Food and Agriculture Organization of the United Nations. 2009 Global agriculture towards 2050. Accessed September 2016. http:// www.fao.org/fileadmin/templates/wsfs/docs/Issues_papers/ HLEF2050_Global_Agriculture.pdf.

Gleeson, T., Y. Wada, M. F. P. Bierkens, and L. P. H. van Beek. 2012 Water balance of global aquifers revealed by groundwater footprint. Nature 488:197-200.

Higham, C. D., D. Horne, R. Singh, B. Kuhn-Sherlock, and M. R. Scarsbrook. 2017. Water use on nonirrigated pasture-based dairy farms: Combining detailed monitoring and modeling to set benchmarks. J. Dairy Sci. 100:828-840.

Kmoch, A., H. Klug, A. B. H. Ritchie, J. Schmidt, and P. A. White. 2015. A spatial data infrastructure approach for the characterization of New Zealand's groundwater systems. Trans. GIS 20:626641.

Meyer, U., M. Everinghoff, D. Gadeken, and G. Flachowsky. 2004 Investigations on the water intake of lactating dairy cows. Livest. Prod. Sci. 90:117-121.

Molle, F., P. Wester, and P. Hirsch. 2010. River basin closure: Processes, implications and responses. Agric. Water Manage. 97:569-577.

Moriasi, D. N., J. G. Arnold, M. W. Van Liew, R. L. Bingner, R. D. Harmel, and T. L. Veith. 2007. Model evaluation guidelines for systematic quantification of accuracy in watershed simulations. Trans. ASABE 50:885-900. 
Murphy, E., I. J. M. de Boer, C. E. van Middelaar, N. M. Holden, L. Shalloo, T. P. Curran, and J. Upton. 2017. Water footprinting of dairy farming in Ireland. J. Clean. Prod. 140:547-555.

Murphy, M. R., C. L. Davis, and G. C. McCoy. 1983. Factors affecting water consumption by Holstein cows in early lactation. J. Dairy Sci. 66:35-38.

R Core Team. 2015. R: A Language and Environment for Statistical Computing. R Foundation for Statistical Computing, Vienna, Austria.

Ramsbottom, G., B. Horan, D. P. Berry, and J. R. Roche. 2015. Factors associated with the financial performance of spring-calving, pasture-based dairy farms. J. Dairy Sci. 98:3526-3540.

Reinmann, D. J. 2003. Milking parlor types. Vol. 2016. Accessed September 2016. http://milkquality.wisc.edu/wp-content/ uploads/2011/09/milking-parlor-types.pdf.

Ridoutt, B. G., and S. Pfister. 2010. A revised approach to water footprinting to make transparent the impacts of consumption and production on global freshwater scarcity. Glob. Environ. Change Human Policy Dimens. 20:113-120.

Scarsbrook, M. R., and A. R. Melland. 2015. Dairying and water quality issues in Australia and New Zealand. Anim. Prod. Sci. $55: 856-868$.
Smakhtin, V., C. Revenga, and P. Doll. 2004. Taking into Account Environmental Water Requirements in Global-Scale Water Resources Assessments. Comprehensive Assessments Research Report No. 2. Comprehensive Assessments Secretariat, Colombo, Sri Lanka.

Sobek, S., L. J. Tranvik, and J. J. Cole. 2005. Temperature independence of carbon dioxide supersaturation in global lakes. Glob. Biogeochem. Cycles 19:GB2003.

Tabesh, M., A. H. A. Yekta, and R. Burrows. 2009. An integrated model to evaluate losses in water distribution systems. Water Resour. Manage. 23:477-492.

United Nations Department of Economic and Social Affairs. 2015. World population prospects: The 2015 revision. Accessed September 2016. https://esa.un.org/unpd/wpp/publications/files/ key_findings_wpp_2015.pdf.

United Nations Educational, Scientific and Cultural Organization. 2015. Water for a sustainable world. Accessed September 2016. http://unesdoc.unesco.org/images/0023/002318/231823E.pdf.

Wold, S., M. Sjöström, and L. Eriksson. 2001. PLS-regression: A basic tool of chemometrics. Chemom. Intell. Lab. Syst. 58:109-130.

Zonderland-Thomassen, M. A., and S. F. Ledgard. 2012. Water footprinting - A comparison of methods using New Zealand dairy farming as a case study. Agric. Syst. 110:30-40. 